University of Nebraska - Lincoln

DigitalCommons@University of Nebraska - Lincoln

1954

Polyvinyl Alcohol-Fixative-Adhesive for Small Helminths and

Protozoa

Glenn L. Hoffman

US Fish and Wildlife Service

Follow this and additional works at: https://digitalcommons.unl.edu/usfwspubs

Part of the Aquaculture and Fisheries Commons

Hoffman, Glenn L., "Polyvinyl Alcohol-Fixative-Adhesive for Small Helminths and Protozoa" (1954). US

Fish \& Wildlife Publications. 121.

https://digitalcommons.unl.edu/usfwspubs/121

This Article is brought to you for free and open access by the US Fish \& Wildlife Service at DigitalCommons@University of Nebraska - Lincoln. It has been accepted for inclusion in US Fish \& Wildlife Publications by an authorized administrator of DigitalCommons@University of Nebraska - Lincoln. 


\title{
POLYVINYL ALCOHOL-FIXATIVE-ADHESIVE FOR SMALL HELMINTHS AND PROTOZOA
}

\author{
GLenN L. Hoffman \\ University of North Dakota, Grand Forks
}

Following the method of Brooke and Goldman (1949), the author was able to fix, mount and stain small helminths and parasitic protozoa of fish in polyvinyl alcohol-fixative smears. However, because there was much granular material in the PVA-Schaudin's mixture, AFA fixative was substituted for the Schaudin's. The PVA went into solution readily using this fixative. The solution was accomplished by adding 5 grams Elvanol \#71-301 to $62 \mathrm{ml}$. of water, heating to $95^{\circ} \mathrm{C}$. until dissolved and adding $5 \mathrm{ml}$. of acetic acid, $11 / 2 \mathrm{ml}$. of glycerine, $10 \mathrm{ml}$. of formaldehyde, and $30 \mathrm{ml}$. of 95 percent alcohol.

Protozoa were placed on a slide in a drop of water; 2 drops of PVA-AFA were added and the mixture spread over approximately one-half of the slide. The slide was dried two days at room temperature or overnight in the $55^{\circ} \mathrm{C}$. oven. This mixture appeared to fix Trichodina, Myxosoma spores, Oxytricha, and Paramecium as well as the PVA-Schaudin's mixture.

After drying, the slides were stained, dehydrated and mounted as ordinary smears. In no instance did the smears come off. As Brooke and Goldman (1949) noted, the slides can be re-dried at any stage before dehydration prior to mounting.

As many live cercariae as could be collected in a drop were placed on a slide and two drops of the PVA-AFA mixture added. This was spread out and allowed to dry as for protozoa. Cercariae of Posthodiplostomum m. minimum and Crassiphiala bulboglossa were fixed in a slightly contracted state but were satisfactory for staining. The slides were stained and mounted with very little loss of material. Previously fixed cercariae can be handled in the same manner. Those fixed in hot 5-10 percent formaldehyde and then attached to the slide with PVA should yield excellent specimens.

Small metacercariae and nematodes that are so easily lost during handling were fixed in a small Petri dish or beaker of hot 10 percent neutralized formaldehyde, transferred to a slide in a drop of fixative, and one drop of PVA-AFA was added. Slides were dried, stained, and mounted as before. The metacercariae of Uvulifer, Crassiphiala, Diplostomulum, Ornithodiplostomum, and the small nematode, Rhabdochona, were easily handled by this method. Hot AFA fixative caused the worms to stick to the container and they were damaged in removal. However, hot formaldehyde alone did not cause them to stick but did prevent extreme contraction. Small helminths can be fixed directly in the PVAAFA solution on a slide, but they contract as they do in any cold fixation. Attempts to anesthetize the worms in 0.4 percent chloretone previous to mounting in the PVA-AFA solution also resulted in contracted speci-

${ }^{1}$ Courtesy of Electrochemicals Department, E. I. DuPont deNemours Co., 7 S. Dearborn Street, Chicago 3, Illinois. 
mens. Dropping hot PVA-AFA onto the worms on a slide likewise resulted in contracted specimens. Trematode ova were badly distorted when mounted directly in cold PVA-AFA.

\section{References Cited}

Brooke, M. M., and Goldman, M. 1949. Polyvinyl Alcohol-Fixative as a Preservative and Adhesive for Protozoa in Dysenteric Stools and Other Liquid Materials. Jour. Lab. Clin. Med., 34:1554-1560. 